\title{
KORELASI HARGA DIRI DAN PENERIMAAN SOSIAL TERHADAP KEPRIBADIAN YANG SEHAT PADA MAHASISWA STT JAFFRAY MAKASSAR
}

\author{
Peniel Maiaweng \\ Penile 68@yahoo.com \\ sttjaffraymakassar@yahoo.co.id
}

\begin{abstract}
ABSTRAK
Penelitian ini bertujuan untuk mengetahui dan menjelaskan korelasi harga diri dan penerimaan sosial terhadap kepribadian yang sehat pada mahasiswa Sekolah Tinggi Theologia Jaffray Makassar. Harga diri mahasiswa menyangkut penilaian individu mahasiswa terhadap dirinya sendiri atau pandangan keseluruhan individu tentang dirinya sendiri. Penerimaan sosial menyangkut penilaian orang lain terhadap individu, partisipasi aktifnya dalam kegiatan sosial,dan memiliki sikap yang bersahabat dengan oran lain. Jika harga diri dan penerimaan sosial yang dimiliki individu baik, maka ia akan mampu menilai diri, situasi. Dan prestasi yang dicapainya secara realistik; mampu menerima tanggung jawab yang dipercayakan kepadanya; mandiri; dapat menguasai emosi; memiliki pertimbangan yang matang; respek dan empati terhadap orang lain; memiliki filsafat hidup berdasarkan keyakinan agama; dan merasa berbahagia.

Metode penelitian adalah survey-kuantitatif yang meneliti para mahasiswa STT Jaffray Makassar. Jumlah populasi mahasiswa STT Jaffray Makassar yang diteliti sebanyak 128. Teknik pengambilan sampel secara random sebanyak 91. Data yang terkumpul dianalisa dengan skala tinggi, rendah, sedang, dan rendah dari setiap varibel yang ada.

Hasil penelitian menunjukkan bahwa terdapat korelasi yang signifikan antara harga diri dan penerimaan sosial terhadap kepribadian yang sehat pada mahasiswa STT Jaffray Makassar dengan nilai korelasi sumbangsih harga diri dan penerimaan sosial terhadap kepribadian yang sehat sebesar 31,5\%, sedangkan 68,5\% dipengaruhi oleh factor-faktor yang lain.
\end{abstract}

Kata Kunci: Harga Diri, Penerimaan Sosial, dan Kepribadian yang Sehat. 


\section{PENDAHULUAN}

\section{Latar Belakang}

Sekolah Tinggi Filsafat Theologia (STFT) Jaffray adalah lembaga pendidikan teologi yang pengajarannya bersumber pada Alkitab sebagai sumber penyataan Allah yang tertulis, dengan tujuan, mempersiapkan para mahasiswa menjadi pemimpin dalam bidang keagamaan Kristen di tengahtengah masyarakat dan menjadi pendeta yang akan memimpin jemaat/gereja yang adalah titipan Allah untuk dilayani. Mengingat pentingnya tujuan dan orientasi pelayanan tersebut, maka para mahasiswa harus mengenal harga diri mereka dan bagaimana mereka diterima secara sosial di lingkungan di mana mereka berada sebagai dasar untuk menilai sehat tidaknya kepribadian mereka sebelum mereka terjun dalam pelayanan untuk melayani jemaat dan masyarakat.

Harga diri (self-esteem) adalah penilaian atau perkiraan seseorang terhadap dirinya sendiri. Pengenalan terhadap harga diri yang dimiliki seseorang adalah penting baginya karena akan mempengaruhi cara ia menjalani hidupnya, penerimaan terhadap dirinya, bagaimana ia menjalani relasi dengan orang lain (Lyness, 2009). Harga diri yang dimiliki seseorang akan sangat berpengaruh kepada kepribadiannya, secara khusus mahasiswa. Menurut Sellet dan Littlefiel, kurangnya harga diri pada mahasiswa dapat mengakibatkan masalah akademik dan penampilan sosial (Sellet dan Littlefield, 2000 dalam Sulistiyowati, 2008). Masalah-masalah lain secara sosial yang akan muncul jika seorang memiliki harga diri yang rendah adalah sebagai berikut (Dahler, 1983 dalam Sobur, 2003: 336-337):

1. Tidak mampu melakukan persahabatan, mengisolasikan diri.

2. Daya Konsentrasi buyar, ketekunan dalam pekerjaan hancur, terlalu banyak melamun.

3. Penyangkalan terhadap nama, asal usul, suku bangsa, masa lampau, dan sebagainya.

4. Tidak mampu memperjuangkan diri, bahkan kadang-kadang timbul keinginan untuk mengakhiri hidup, bertalian dengan kebosanan hidup.

5. Sifat ingin membalas dendam; bereaksi terlalu radikal terhadap orang lain maupun dirinya sendiri; tidak mengakui dan menerima masa lampaunya, lalu mau merubah diri secara sangat radikal (identitas negative).

Berbeda dengan orang yang memiliki harga diri yang positif. Menurut Vaughan dan Hogg,

Harga diri yang positif membuat orang dapat mengatasi kecemasan, kesepian, dan penolakan sosial. Dalam hal ini, harga diri menjadi 'alat ukur sosial' (sociometer) untuk melihat sejauh mana seseorang merasa 
diterima dan menyatu dengan lingkungan sosialnya. Dengan demikian, semakian, semakin positif harga diri yang dimiliki, semakin menunjukkan bahwa ia semakin merasa diterima dan menyatu dengan orang-orang di sekitarnya (Vaughan dan Hogg, 2002 dalam Sarwono dan Meinarno, 2009: 57).

Penelitian yang dilaksanakan oleh Sulistiyowati pata tahun 2008 tentang Hubungan antara Harga Diri dengan Motivasi Belajar Mahasiswa Semester II dan IV Kebidanan Universitas Negeri Sebelas Maret menunjukkan bahwa mereka yang mempunyai harga diri tinggi akan lebih berhasil dalam menyesuaikan diri dalam menyelesaikan masalah (Sulistyowati: 2008).

Ini menunjukkan bahwa tanda kepribadian yang sehat adalah jika seorang mahasiswa harga diri dan penerimaan sosial yang baik. Jika ia memiliki harga diri yang baik, maka ia akan menempatkan diri secara benar dalam lingkungan sosial di mana ia berada sehingga ia dapat diterima agar pelayanan yang dilaksanakanya pun diterima dengan baik. Hal tersebut juga akan sangat berpengaruh kepada sehat tidaknya kepribadiannya. Jika harga dirinya baik dan penerimaan sosial yang dialaminya pun baik menunjukkan bahwa ia memiliki kepribadian yang sehat. Atau sebaliknya, jika ia tidak memiliki harga diri yang baik dan penerimaan sosial yang tidak baik, maka ia memiliki kepribadian yang tidak sehat.

Berdasarkan pengamatan penulis selama empat tahun, banyak di antara mahasiswa STT Jaffray Makassar yang bermasalah dengan harga diri dan penerimaan sosial, tidak mampu menjalin persabatan dengan baik bersama mahasiswa-mahasiswa yang tidak sesuku, sekampung, sehobi, seangkatan, sekonsentrasi, bahkan ada yang mengisolasi diri untuk tidak bergaul dengan orang lain. Ini sebagai gambaran bahwa mahasiswa tidak semua mahasiswa memiliki kepribadian yang sehat yang didasarkan pada harga diri dan penerimaan sosial.

Mengingat pentingnya memahami harga diri dan penerimaan sosial terhadap kepribadian yang sehat, maka dilakukan penelitian dengan judul "Korelasi antara Harga Diri dan Penerimaan Sosial terhadap Kepribadian yang Sehat pada Mahasiswa Sekolah Tinggi Filsafat Theologia Makassar," yang mana hasilnya akan menjadi input bagi peneliti dan STT Jaffray untuk melaksanakan pembinaan kepada mahasiswa yang mengarah kepada harga diri dan penerimaan sosial agar memiliki kepribadian yang sehat.

\section{Rumusan Masalah}

Masalah pokok dari penelitian ini adalah "Apakah terdapat korelasi antara harga diri dan penerimaan sosial terhadap pembentukan kepribadian yang sehat pada mahasiswa STT Jaffray Makassar?" Dengan rumusan masalah:

1. Apa tingkat harga diri yang dimiliki oleh para mahasiswa?

2. Apa tingkat penerimaan sosial yang dialami oleh para mahasiswa? 
3. Bagaimana harga diri dan penerimaan sosial yang dimiliki oleh para mahasiswa berpengaruh terhadap kepribadian yang sehat?

\section{Tujuan Penelitian}

Tujuan umum penelitian adalah untuk mengetahui hubungan antara harga diri dan penerimaan sosial terhadap pembentukan kepribadian yang sehat pada mahasiswa STT Jaffray Makassar. Tujuan khusus adalah:

1. Menguraikan tingkat harga diri mahasiswa STT Jaffray.

2. Menguraikan tingkat penerimaan sosial yang dialami oleh mahasiswa STT Jaffray.

3. Menguraikan sehat tidaknya kepribadian mahasiswa STT Jaffray berdasarkan pemahaman tingkat harga diri dan tingkat penerimaan sosial.

\section{Manfaat Penelitian}

1. Sebagai masukan bagi mahasiswa yang diteliti untuk dapat mengenal harga diri, penerimaan sosial, dan kepribadian yang sehat yang dimilikinya.

2. Sebagai masukan bagi STT Jaffray untuk mengenal tingkat harga diri, penerimaan sosial, dan kepribadian yang sehat yang dimiliki oleh para mahasiswa yang sedang menjalani pendidikan di perguruan tinggi ini.

3. Sebagai acuan bagi STT Jaffray Makassar untuk merancang kegiatankegiatan secara akademik dan non-akademik untuk menolong mahasiswa secara psikologis agar dapat memiliki harga diri dan penerimaan sosial yang baik serta memiliki kepribadian yang baik.

\section{TINJAUAN PUSTAKA}

\section{Pengenalan tentang Harga Diri}

Harga diri atau self-esteem (to estimate) adalah taksiran diri atau penilaian diri. Dengan maksud, harga diri yang dimiliki seseorang ditentukan oleh penilaian dan prakiraannya terhadap dirinya sendiri. Menurut Santrock, harga diri adalah "Pandangan keseluruhan dari individu tentang dirinya sendiri” (Santrock, 2008: 113). Menurut Coopersmith, harga diri adalah "Penilaian yang dibuat seseorang dan biasanya tentang dirinya; hal itu menyatakan sikap menyetujui, dan menunjukkan sejauh mana orang menganggap dirinya mampu, berarti dan berharga" (dalam Harre \& Lamb, 1996: 274-275). Menurut Les Parrott III, harga diri adalah evaluasi infomasi tentang diri yang terkandung dalam konsep diri (1993: 163). Dengan demikian dapat disimpulkan bahwa harga diri adalah 
pandangan dan penilaian individu tentang hal-hal yang berkaitan dengan keseluruhan dirinya, dengan sikap menyutuji atau tidak, dan menyatakan keyakinan individu tentang dirinya sebagai pribadi yang mampu, penting, dan berharga.

Orang-orang yang memiliki harga diri yang baik dapat melakukan yang baik dalam pendidikannya dan dengan mudah membangun relasi dengan orang lain. Mereka cenderung memiliki relasi yang baik dengan teman-teman sebaya dan orang yang lebih dewasa dan lebih bahagia. Mereka dengan mudah dapat mengatasi kekecewaan, kesalahan dan kegagalan yang mereka alami. Mereka dengan jujur dan terbuka meminta bantuan dari orang lain jika mereka mengalami masalah. (Lyness, 2009). Sedangkan orang yang memiliki harga diri rendah akan kurang mempercayai dirinya sendiri, memiliki kecemburuan dan mengritik orang lain, cenderung menarik diri dari lingkungan sosial, memiliki kecenderungan untuk mengeluh, tidak toleran, sangat sensitif, sulit mengampuni,sulit untuk menerima pujian, dan sulit untuk mengekspresikan kasih sayang (Ellison, 1985: 1045-1047 dalam Collins, 1988: 320).

\section{Pengenalan tentang Penerimaan Sosial}

Penerimaan sosial adalah "Individu dinilai positif oleh orang lain, mau berpartisipasi aktif dalam kegiatan sosial, dan memiliki sikap bersahabat dalam berhubungan dengan orang lain" (E. B. Hurlock, 1986 dalam Yusuf LN, 2000, 131). Penerimaan sosial terjadi karena adanya kematangan dalam hubungan sosial sebagai pencapaian proses pembelajaran dalam menyesuaikan diri dengan norma-norma kelompok, moral, dan tradisi, yang mana individu dapat meleburkan diri menjadi satu kesatuan dan saling berkomunikasi dan bekerja sama (Yusuf LN, 2000: 122).

Penerimaan sosial setiap individu sangat dipengaruhi oleh lingkungan sosialnya, yaitu orangtua, sanak keluarga, orang dewasa lainnya, dan teman sebaya (Yunus LN, 2000: 125). Terbentuknya kepribadian yang sehat yang dimiliki oleh individu bergantung pada penerimaan lingkungan sosial yang dialaminya. Jika lingkungan sosial memfasilitasi dan memberikan kesempatan kepada inividu secara positif, maka individu akan mengalami perkembangan secara positif. Jika lingkungan sosial tidak kondusif, seperti perlakukan yang kasar dari orangtua, pengajar di sekolah, dan orang-orang yang berada di sekitarnya; individus sering dimahari, acuh tak acuh; tidak memberikan bimbingan dan teladan; tidak ada pengajaran dan pembiasaan terhadap individu dalam menerapkan norma-norma agama maupun tata karma yang baik, maka individu akan menunjukkan prilaku maladjustment, seperti minder, suka mendominasi orang lain, egois dan selfish, mengisolasi diri, kurang memiliki tenggang rasa, kurang mempedulikan norma dan berperilaku (Yunus L.N., 2000: 125-126). 


\section{Pengenalan tentang Kepribadian Yang Sehat}

Kepribadian adalah "Kualitas perilaku individu yang tampak dalam melakukan persesuaian diri terhadap lingkungan secara unik" (Abin Syamsuddin Makmun, 1996 dalam Yunus LN, 2000: 127). Tanda-tanda kepribadian yang sehat memiliki karakteristik sebagai berikut (E. B. Hurlock, 1986 dalam Yunus LN, 2000: 130-131):

1. Mampu minilai diri secara realistik. Kemampuan menilai dirinya sebagaimana adanya, baik kelebihan dan kekurangan atau kelamehannya, menyangkut faktor fisik (postur tubuh, wajah, keutuhan, dan kesehatan) dan kemampuan diri.

2. Mampu menilai situasi secara realistik. Kemampuan menghadapi situasi atau kondisi hidup secara realistic dan menerimanya secara wajar, bahkan tidak mengharapkan kondisi hidup yang sempurna.

3. Mampun menilai prestasi secara realistik. Kemampuan menerima prestasi dan keberhasilannya secara realistik dan rasional. Tidak sombong saat mengalami prestasi yang tinggi dan bersikap optimistik apabila mengalami kegagalan.

4. Menerima tanggung jawab. Kemampuan untuk mengatasi masalahmasalah yang dihadapinya.

5. Kemandirian (autonomi). Kemandirian dalam berpikir dan bertindak, serta mampu mengambil keputusan, mampu mengarahkan dan mengembangkan diri, dan mampu menyesuaikan diri dengan norma yang berlaku di lingkungannya.

6. Dapat mengontrol emosi. Merasa aman dengan perasaannya dan dapat mengahadapi situasi yang menyebabkan frustrasi dan depresi secara positif, dan tidak destruktif.

7. Berorientasi pada tujuan. Kemampuan merumuskan tujuan hidup berdasarkan pertimbangan yang matang, bukan paksaan dari luar, dan berupaya mencapai tujuan tersebut berdasarkan pengembangan kepribadian dan ketrampilan.

8. Berorientasi keluar. Respek terhadap orang lain, empati terhadap orang lain, menghargai orang lain seperti dirinya sendiri, tidak membiarkan dirinya menjadi orang lain, dan tidak membuat orang lain menjadi korban.

9. Memiliki filsafat hidup. Kemampuan mengarahkan hidup berdasarkan filsafat hidup yang berdasar pada keyakinan agama.

10. Berbahagia. Merasa berbahagia karena prestasi yang diraih, penerimaan dari orang lain, dan perasaan dicintai dan disayangi oleh orang lain.

\section{Korelasi Harga Diri dan Penerimaan Sosial} terhadap Kepribadian yang Sehat

Kepribadian yang sehat yang dimiliki seseorang bergantung pada bagaimana ia menilai dirinya dan pengeruhnya terhadap tingkah lakunya. Dicky C. Pelupessy berpendapat: 
Tingkah laku sosial seseorang dipengaruhi oleh pengetahuan tentang siapa dirinya. Namun, tingkah laku sosial seseorang juga dipengaruhi oleh penilaian atau evaluasi dirinya, baik secara positif atau negative. Jika orang menilai secara positif terhadap dirinya, maka ia menjadi percaya diri dalam mengerjakan hal-hal yang ia kerjakan dan memperoleh hasil yang positif pula. Sebaliknya, orang yang menilai secara negative terhadap dirinya, menjadi tidak percaya diri ketika mengerjakan sesuatu dan pada akhirnya, hasil yang didapatkan pun tidak menggembirakan (Sarwono \& Meinarno, 2009: 57).

Seorang yang memiliki penghargaan diri rendah adalah karena mereka tidak diberi dukungan emosional dan penerimaan sosial yang memadai (Carl Rogers 1961 dalam Santrock, 2008: 113). Berdasarkan teori-teori yang ada menunjukkan bahwa iika seorang memiliki harga diri rendah dan tidak mengalami penerimaan sosial yang baik, maka ia tidak memiliki kepribadian yang sehat.

\section{METODE PENELITIAN}

\section{Identifikasi Variabel}

1. Variabel independent, yaitu
a. Harga diri (xl).
b. Penerimaan sosial (x2).

2. Variabel dependent, yaitu Kepribadian Yang Sehat (yl).

\section{Definisi Operasional}

1. Harga Diri adalah penilaian atau evaluasi secara positif atau negative terhadap diri (Deaux, Dane, \& Wrightsman, 1992 dalam Sarwono dan Meinarno, 2009: 57).

2. Penerimaan Sosial adalah individu dinilai positif oleh orang lain, mau berpartisipasi aktif dalam kegiatan sosial, dan memiliki sikap bersahabat dalam berhubungan dengan orang lain" (E. B. Hurlock, 1986 dalam Yusuf LN, 2000, 131).

3. Kepribadian Yang Sehat adalah "Kualitas perilaku individu yang tampak dalam melakukan persesuaian diri terhadap lingkungan secara unik" (Abin Syamsuddin Makmun, 1996 dalam Yunus LN, 2000: 127).

\section{Tempat dan Subyek Penelitian}

Tempat penelitian adalah Kampus Sekolah Tinggi Filsafat Theologia (STFT) Jaffray Makassar, Jalan Gunung Merapi 103 Makassar. Subyek penelitian adalah Mahasiswa STT Jaffray angkatan 2006-2009.

\section{Populasi dan Sampel}

Populasi yang menjadi fokus dari penelitian ini adalah mahasiswa Sekolah Tinggi Theologia Jaffray Makassar angkatan 2006-2009 dengan 
jumlah 128 orang. Dari jumlah anda dilaksanakan pengambilan sampel secara acak dengan mengacu kepada table Krejcie - Morgan dengan tingkat kesalahan $5 \%$. Dengan demikian jumlah sampel yang digunakan dari populasi yang adalah sebanyak 91 yang dapat mewakili populasi dari penelitian ini.

\section{Alat Pengumpulan Data}

1. Skala Harga Diri

Alat pengumpulan data untuk skala harga diri yang merupakan gabungan dari beberapa self-esteem inventory yang dimodifikasi untuk penelitian ini. Pengkuran variable menggunakan skala Likert ini terdiri dari 4 alternatif jawaban, yaitu Sangat Setuju (SS), Setuju (S), Kurang Setuju (KS), Tidak Setuju (TS), dan Sangat Tidak Setuju (STS). Makin tinggi skor jawaban, maka harga diri seseorang semakin baik, dan sebaliknya, semakin rendah skor, maka cenderung memiliki harga diri rendah.

2. Skala Penerimaan Sosial

Alat pengumpulan data untuk skala penerimaan sosial adalah socialacceptance inventory yang dibuat berdasarkan faktor-faktor yang berkaitan dengan penerimaan sosial, seperti orangtua, teman sekampus, dosen, dan Tuhan. Pengkuran variable menggunakan skala Likert ini terdiri dari 4 alternatif jawaban, yaitu Sangat Setuju (SS), Setuju (S), Tidak Setuju (TS), dan Sangat Tidak Setuju (STS). Makin tinggi skor jawaban, maka penerimaan sosial seseorang semakin baik, dan sebaliknya, semakin rendah skor, maka cenderung memiliki penerimaan sosial yang rendah.

3. Skala Kepribadian Yang Sehat

Alat pengumpulan data untuk skala kepribadian yang sehat adalah healthy personality inventory yang dimodifikasi, dengan berfokus pada penilaian diri secara realistik, penilaian situasi secara realistik, penilaian prestasi yang diperoleh secara realistik, penerimaan tanggung jawab, kemandirian, pengontrolan emosi, orientasi pada tujuan, orientasi pada keluar, penerimaan sosial, filsafat hidup, kebahagiaan. Pengkuran variable menggunakan skala Likert ini terdiri dari 4 alternatif jawaban, yaitu Sangat Setuju (SS), Setuju (S), Tidak Setuju (TS), dan Sangat Tidak Setuju (STS). Makin tinggi skor jawaban, maka kepribadian seseorang semakin sehat, dan sebaliknya, semakin rendah skor, maka cenderung kepribadian seseorang tidak sehat.

\section{Rancangan Penelitian}

Rancangan penelitian yang digunakan dalam penelitian ini adalah penelitian kuantitatif, dengan menggunakan metode survey. Metode survey adalah metode penelitian yang dilakukan pada populasi besar maupun kecil, tetapi data yang dipelajari adalah data dari sampel yang diambil dari 
populasi tersebut, sehingga ditemukan hubungan-hubungan antar variable yaitu harga diri, penerimaan sosial, dan kepribadian yang sehat. Sampel yang digunakan adalah mahasiswa Sekolah Tinggi Theologia Jaffray Makassar angkatan 2005-2009.

\section{Teknik Pengumpulan Data}

Teknik pengumpulan data dalam penelitian ini adalah menggunakan koesioner dengan jumlah pertanyaan sebanyak 113, dengan klasifikasi, harga diri digunakan self-esteem inventory yang dimodifikasi berdasarkan kebutuhan penelitian sebanyak 47 pertanyaan yang bersifat favorable dan unfavorable; tentang penerimaan sosial digunakan social acceptance inventory yang dimodifikasi sesuai kebutuhan sebanyak 19 pertanyaan yang bersifat favorable dan unfavorable; dan tentang kepribadian yang sehat (healthy personality inventory) sebanyak 37 pertanyaan yang dimodifikasi sesuai dengan kebutuhan yang bersifat favorable dan unfavorable. Adapun alternative jawaban dinilai sebagai berikut:

Jawaban Sangat Setuju nilai skor 4

Jawaban Setuju nilai skor 3

Jawaban Tidak Setuju nilai skor 2

Jawaban Sangat Tidak Setuju nilai skor 1

\section{Teknik Pengolahan/Analisa Data}

Teknik pengolahan adalah editing, yaitu meneliti jawaban-jawaban yang telah diberikan oleh para responden untuk mengetahui apakah jawaban yang diberikan telah sesuai dengan pentunjuk pengisian kuesioner dengan cara meneliti dan mengoreksi satu persatu jawaban; dan tabulasi, yaitu memberikan skor terhadap setiap jawaban yang diberikan responden berdasarkan skala pengukuran yang ditentukan.

Teknik analisis data yang digunakan dalam penelitian ini adalah menggunakan SPSS 17 for Windows.

1. Analisis Responden.

Analisis Responden digunakan untuk mengetahui validitas responden dengan kategori-kategori responden yang diteliti.

2. Uji Validitas dan Reliabilitas Instrumen.

Uji validitas dimaksudkan untuk mengukur sejauhmana instrument penelitian yang digunakan untuk mendapatkan dan mengukur data dengan tepat berlaku untuk variable-variabel yang diteliti.

3. Analisis Statistik Deskriptif.

Analisis deskriptif digunakan untuk mendeskipsikan ciri-ciri variable yang diteliti atau merangkum hasil pengamatan penelitian yang telah dilakukan tanpa membuat kesimpulan yang berlaku untuk umum dari data yang diperoleh dari sampel, dengan menentukan nilai mean (nilai rata-rata), median (nilai di tengah skor yang ada), dan modus (nilai yang frekuensinya paling banyak). 
4. Analisis Taburan Normalitas.

Digunakan untuk membuktikan analisis normalitas data dari variablevariabel dalam penelitian ini.

5. Uji Anova Satu Arah

Uji Anova digunakan untuk menguji perbedaan skor-skor rata-rata (mean) yang signifikan bagi tiga atau lebih kelompok variabel sama atau berbed. Uji Anova digunakan untuk mengetahui apakah terdapat perbedaan lebih dari satu variabel, seperti korelasi harga diri dan penerimaan sosial terhadap kepribadian yang sehat berdasarkan jenis kelamin, umur, angkatan, konsentrasi, indeks prestasi, status pernikahan. Uji Anova juga digunakan untuk menentukan apakah hipotesis ditolah atau diterima untuk menentukan perbedaan kepada sampel kajian.

6. Analisis Korelasi

Analisis Korelasi adalah analisa yang dilaksanakan untuk melihat hubungan antara variabel-variabel dan menguji serta menjawab hipotesis berbentuk asosiatif. Analisis Korelasi digunakan untuk melihat kekuatan hubungan antara variabel bebas (independent) dan variabel terikat (dependent).

7. Analisis Regresi Berganda

Analisis Regresi digunakan untuk memprediksikan pengaruh nilai variabel dependent (terikat) berdasarkan nilai variabel independent (bebas). Analisis Regresi dilakukan untuk mengetahui hubungan antara dua variabel atau lebih yang bersifat kasual (sebab akibat). Analisis Regresi digunakan juga untuk menjawab hipotesis Nol tentang pengaruh dua atau lebih variabel bebas terhadap variabel terikat.

\section{Jadwal Penelitian}

Penelitian dilaksanakan pada April 2010 sampai dengan Agustus

2010, dengan pembagian waktu sebagai berikut:

1. Pembuatan dan Seminar Proposal Maret 2010

2. Pembuatan angket April 2010.

3. Pengedaran dan pengumpulan angket Mei dan Juni 2010.

4. Analisa dan Penyimpulan data Juli 2010.

5. Seminar hasil Agustus 2010.

6. Penyerahan hasil penelitian September 2010. 


\section{ANALISA DAN PEMBAHASAN}

\section{Analisis Data Responden}

Jenis Kelamin

Data responden berdasarkan jenis kelamin berjumlah 91 yang terdiri dari pria sebanyak 49 dan wanita sebanyak 42 .

Usia

Umumnya usia mahasiswa yang menjadi responden berkisar antara 21-24 tahun sebanyak 44 orang karena merekalah usia produktif dalam pendidikan perguruan tinggi, sedangkan 17-20 tahun sebanyak 23 orang, 25-30 tahun sebanyak 19 orang, 31 tahun ke atas sebanyak tiga orang, dan kosong sebanyak 2 orang.

\section{Angkatan}

Berdasarkan tahun masuk, responden terbanyak adalah angkatan 2009 berjumlah 33 orang adalah angkatan yang baru masuk. Berikutnya angkata 2006 adalah angkatan yang akan melaksanakan praktek lapangan sebanyak 21 orang, angkatan 2008 berjumlah 17 orang, angkatan 2007 berjumlah 18 orang, dan kosong sebanyak 2 orang.

\section{Konsentrasi Program}

Responden berdasarkan konsentrasi program, terbanyak dari konsentrasi Pendidikan Agama Kristen (37) dan Ilmi Teologi (33) karena kedua konsentrasi inilah yang memiliki banyak mahasiswa, dan disusul dengan konsentrasi Musik (17) dan Pelayanan Anak/Remaka (4) yang adalah program terbaru.

\section{Indeks Prestasi}

Berdasarkan indeks prestasi, responden terbanyak adalah mereka yang memiliki IP antara 3,00-3,49 (38 orang), disusul dengan 2,50-2,99 (19 orang), 3,50-4,00 (17 orang), kosong (15 orang), dan 1,00-1,99 (2 orang).

\section{Status Pernikahan}

Berdasarkan status pernikahan, sebagian besar responden adalah orang-orang yang belum menikah (84 orang), disusul dengan menikah (2 orang), dan yang tidak mengisi (5 orang).

\section{Uji Validitas dan Reliabilitas Instrumen}

Uji validitas dimaksudkan untuk mengukur sejauhmana instrument penelitian yang digunakan untuk mendapatkan dan mengukur data dengan tepat berlaku untuk variable-variabel yang diteliti.

Keputusan analisis menunjukkan bahwa korelasi item terendah adalah 0,400 dan statistic alfa cronbach adalah 0,625. Dengan melihat nilai korelasi yang ada (tidak terdapat nilai yang minus), menunjukkan bahwa instrument telah terpenuhi validitas dan reliabilitas instrument dapat digunakan dalam penelitian yang sebenarnya. 


\section{Analisis Statistik Deskriptif}

Analisis deskriptif digunakan untuk mendeskipsikan ciri-ciri variable yang diteliti atau merangkum hasil pengamatan penelitian yang telah dilakukan tanpa membuat kesimpulan yang berlaku untuk umum dari data yang diperoleh dari sampel, dengan menentukan nilai mean (nilai rata-rata), median (nilai di tengah skor yang ada), dan modus (nilai yang frekuensinya paling banyak).

Hasil output menunjukkan bahwa instrument yang digunakan adalah valid. Analisis ini menunjukkan bahwa korelasi antara harga diri dan penerimaan sosial terhadap kepribadian yang sehat memiliki mean (nilai rata-rata) 61, 84; media (nilai di tengah skor yang ada) 62; dan modus (nilai terbanyak) 60 .

\section{Analisis Taburan Normalitas}

Analisa taburan digunakan untuk membuktikan analisis normalitas data dari variable-variabel dalam penelitian ini.

\section{Harga Diri}

Nilai Skeweness -0.092 menunjukkan data dianggap mengikuti taburan distribusi normal apabila Rasio Skeweness = Nilai Skeweness : Std. Erros Skeweness. Dari table di atas diperoleh -0,092 : 0,253=-0,364. Sedangkan nilai Kurtosis -0,0313 menunjukkan ukuran keakuratan mengikuti distribusi normal apabila Rasio Kustosis = Nilai Kustorsis : Std Eror Kurtosis. Dari table di atas diperoleh $-0,313: 0,500=-0,0626$. Maka data tentang harga diri diasumsikan berdistribusi normal.

Untuk uji normalitas mengguna Kolmogorov-Smirnov adalah 0,200 dan Shapiro-Wilk adalah 0,831. Distribusi data normal jika kedua-duanya diuji tidak signifikan >0,05, oleh sebab itu, data di atas adalah normal.

\section{Penerimaan Sosial}

Nilai Skeweness 0.743 menunjukkan data dianggap mengikuti taburan distribusi normal apabila Rasio Skeweness = Nilai Skeweness : Std. Erros Skeweness. Dari table di atas diperoleh 0,092: 0,253= 2.937 . Sedangkan nilai Kurtosis 3,035 menunjukkan ukuran keakuratan mengikuti distribusi normal apabila Rasio Kustosis $=$ Nilai Kustorsis : Std Eror Kurtosis. Dari table di atas diperoleh 3,305:0,500 =6,07. Maka data tentang penerimaan sosial diasumsikan berdistribusi normal.

Untuk uji normalitas mengguna Kolmogorov-Smirnov adalah 0,000 dan Shapiro-Wilk adalah 0,000. Distribusi data normal jika kedua-duanya diuji tidak signifikan < 0,05, oleh sebab itu, data di atas adalah normal.

\section{Kepribadian yang sehat}

Nilai Skeweness 0.573 menunjukkan data dianggap mengikuti taburan distribusi normal apabila Rasio Skeweness = Nilai Skeweness : Std. Erros Skeweness. Dari table di atas diperoleh 0,573: 0,253=0,32. Sedangkan nilai Kurtosis 0,468 menunjukkan ukuran keakuratan mengikuti distribusi normal apabila Rasio Kustosis = Nilai Kustorsis : Std 
Eror Kurtosis. Dari table di atas diperoleh 0,469:0,500 =0,99. Maka data tentang kepribadian yang sehat diasumsikan berdistribusi normal.

\section{Analisa Anova Satu Arah}

Uji Anova digunakan untuk menguji perbedaan skor-skor rata-rata (mean) yang signifikan bagi tiga atau lebih kelompok variabel sama atau berbed. Uji Anova digunakan untuk mengetahui apakah terdapat perbedaan lebih dari satu variabel, seperti korelasi harga diri dan penerimaan sosial terhadap kepribadian yang sehat berdasarkan jenis kelamin, umur, angkatan, konsentrasi, indeks prestasi, status pernikahan. Uji Anova juga digunakan untuk menentukan apakah hipotesis ditolah atau diterima untuk menentukan perbedaan kepada sampel kajian.

Standar pengujian, apabila Signifikan > (lebih besar) dari alpha $(0,05$ atau $5 \%$ ) maka tidak ada perbedaan yang signifikan di antara kelompok. Apabila Signifikan < (lebih kecil atau sama dengan) alpha maka ada perbedaan yang signifikan antar kelompok.

\section{Berdasarkan Jenis Kelamin}

Analisa Mean (skor rata-rata):

Mean harga diri wanita adalah 62,27 dan pria adalah 61,47 dengan nilai rata-rata 61,48. Mean penerimaan sosial wanita 65,29 dan pria 64,06 dengan nilai rata-rata 64,63. Mean kepribadian yang sehat wanita 66,18 dan pria 65,31 dengan nilai rata-rata 65,71. Ini menunjukkan bahwa harga diri, penerimaan sosial, dan kepribadian yang sehat dari wanita lebih baik dari pria. Ini berarti pula bahwa wanita tampil lebih percaya diri dan menerima dirinya apa dalam relasi sosial sehingga menunjukkan bahwa kepribadian yang sehat dari wanita lebih baik dari pria.

\section{Uji Anova Satu Arah}

1. Nilai F (skor variasi antar kelompok) untuk harga diri berdasarkan jenis kelamin adalah 0,634 sedangkan propabilitas signifikannya adalah 0,428 atau 43\% lebih besar dari alpha (tingkat signifikansi penerimaan dan penolakan) sebesar $5 \%$ atau 0,428>0,05. Ini berarti tidak terdapat perbedaan yang signifikan akan nilai harga diri di dalam maupun di antara kelompok pria dan wanita.

2. Nilai F untuk penerimaan sosial berdasarkan jenis kelamin adalah 1,202 sedangkan propabilitas signifikannya adalah 0,276 (28\%) lebih besar dari alpha 0,05 (5\%) atau 0,276>0,05. Ini berarti tidak terdapat perbedaan yang signifikan akan penerimaan sosial di dalam maupun di antara kelompok pria dan wanita.

3. Nilai F untuk kepribadian yang sehat berdasarkan jenis kelamin adalah 0,735 sedangkan propabilitas signifikansi adalah 0,394 (39\%) lebih besar dari alpha $0,05(5 \%)$. Ini berarti tidak terdapat perbedaan yang signifikan akan kepribadian yang sehat di dalam maupun di antara kelompok pria dan wanita. 


\section{Berdasarkan Umur}

Analisa Mean (Skor rata-rata):

1. Mean harga diri menunjukkan bahwa usia 17-20 tahun memiliki nilai 61,78; usia 21-24 tahun adalah 62,26; usia 25-30 tahun adalah 61,21; usia 31-35 tahun adalah 6l; dan usia di atas 35 tahun adalah 56; dengan nilai rata-rata 61,84. Ini menunjukkan bahwa nilai penerimaan sosial tertinggi adalah usia 17-20 tahun, sedangkan terendah 31-35 tahun. Kemungkinan usia 31-35 merasa bahwa mereka sudah tua dan kadang merasa asing di kampus dan merasa kurang pantas apabila berkumpul dengan mahasiswa yang umumnya berusia belia.

2. Mean penerimaan sosial menunjukkan bahwa usia 17-20 tahun memiliki nilai 65,54; usia 21-24 tahun adalah 65,14; usia 25-30 tahun adalah 63,58; usia 31-35 tahun adalah 57; dan usia di atas 35 tahun adalah 6l. Nilai rata-rata dari mean penerimaan sosial adalah 64,63. Ini menunjukkan bahwa nilai penerimaan sosial tertinggi adalah usia 17-20 tahun, sedangkan terendah 31-35 tahun. Dengan demikian usia 17-20 tahun lebih terbuka untuk membangun relasi sosial dan mengalami penerimaan sosial dibandingkan dengan kelompok usia yang lain.

3. Mean kepribadian yang sehat menunjukkan bahwa usia 17-20 tahun memiliki nilai 66,85; usia 21-24 tahun adalah 65,09; usia 25-30 tahun adalah 66,63; usia 31-35 tahun adalah 63; dan usia di atas 35 tahun adalah 63. Nilai rata-rata dari mean kepribadian yang sehat adalah 65,71. Ini menunjukkan bahwa nilai kepribadian yang tertinggi adalah usia 17-20 tahun, sedangkan terendah 31-35 tahun dan di atas 35 tahun. Ini berarti usia 17-20 tahun memiliki kepribadian yang lebih sehat dibandingkan dengan kelompok usia yang lain namun perbedaannya tidak terlalu signifikan.

Uji Anova Satu Arah

1. Nilai F untuk harga diri berdasarkan kelompok umur adalah 0,964 sedangkan propabilitas signifikannya adalah 0,445 (45\%) lebih besar dari alpha 0,05 (5\%). Ini berarti bahwa tidak terdapat perbedaan yang signifikan akan nilai harga diri di dalam maupun di antara kelompok umur, baik 17-20 tahun, 21-24 tahun, 25-30 tahun, 31-35 tahun, dan di atas 35 tahun.

2. Nilai F untuk penerimaan sosial berdasarkan kelompok umur adalah 1,199 sedangkan propabilitas signifikannya adalah 0,316 atau 30\% lebih besar dari alpha 5\%. Ini berarti bahwa tidak terdapat perbedaan yang signifikan akan nilai penerimaan sosial di dalam maupun di antara kelompok umur, baik 17-20 tahun, 21-24 tahun, 25-30 tahun, 31-35 tahun, dan di atas 35 tahun.

3. Nilai F untuk kepribadian yang sehat berdasarkan kelompok umur adalah 1,027 sedangkan propabilitas signifikansi adalah 0,407 atau 41\% lebih besar dari alpha 5\%. Ini berarti bahwa tidak terdapat perbedaan yang signifikan akan nilai kepribadian yang sehat di dalam maupun di 
antara kelompok umur, baik 17-20 tahun, 21-24 tahun, 25-30 tahun, 3135 tahun, dan di atas 35 tahun.

\section{Berdasarkan Angkatan}

Analisa Mean (Skor rata-rata):

1. Mean harga diri berdasarkan angkatan menunjukkan bahwa angkatan 2006 memiliki nilai 61,95; angkatan 2007 adalah 61,06; angkatan 2008 adalah 62,29; angkatan 2009 adalah 61,83. Mean keseluruhan untuk harga diri berdasarkan angkatan adalah 61,48. Ini menunjukkan bahwa nilai harga diri tertinggi adalah angkatan 2008, sedangkan terendah adalah angkatan 2007.

2. Mean penerimaan sosial menunjukkan bahwa angaktan 2006 memiliki nilai 63,81; angkatan 2007 adalah 64,17; angkatan 2008 adalah 64,29; angkatan 2009 adalah 65,46. Mean untuk penerimaan sosial berdasarkan angkatan adalah 64,63. Ini menunjukkan bahwa nilai penerimaan sosial tertinggi adalah angkatan 2009, sedangkan terendah adalah angkatan 2006.

3. Mean kepribadian yang sehat menunjukkan bahwa angkatan 2006 memiliki nilai 65,24; angkatan 2007 adalah 66,39; angaktan 2008 adalah 66,12; angkatan 2009 adalah 65,17. Mean untuk kepribadian yang sehat berdasarkan angkatan adalah 65,71. Ini menunjukkan bahwa nilai kepribadian yang tertinggi adalah angkatan 2007, sedangkan terendah adalah angkatan 2009.

Uji Anova Satu Arah

1. Nilai F untuk harga diri berdasarkan angkatan adalah 0,254 sedangkan propabilitas signifikannya adalah 0,906 atau 90\% lebih besar dari alpha $5 \%$. Ini berarti bahwa tidak terdapat perbedaan yang signifikan akan nilai harga diri di antara angkatan 2006, 2007, 2008, 2009.

2. Nilai F untuk penerimaan sosial berdasarkan angkatan adalah 0,424 sedangkan propabilitas signifikannya adalah 0.791 atau $80 \%$ lebih besar dari alpha 5\%. Ini berarti bahwa tidak terdapat perbedaan yang signifikan akan nilai penerimaan sosial di dalam maupun di antara angkatan 2006, 2007, 2008, 2009.

3. Nilai F untuk kepribadian yang sehat berdasarkan angkatan adalah 0,65l sedangkan propabilitas signifikansi adalah 0,625 atau 62,5\% lebih besar dari alpha 5\%. Ini berarti bahwa tidak terdapat perbedaan yang signifikan akan nilai kepribadian yang sehat di dalam maupun di antara angkatan 2006, 2007, 2008, 2009.

\section{Berdasarkan Konsentrasi}

\section{Analisa Mean (Skor rata-rata)}

1. Mean harga diri berdasarkan konsentrasi menunjukkan bahwa Teologi memiliki nilai 61,42; PAK adalah 62,36; Musik adalah 61,76; PAR adalah 60,76. Mean keseluruhan untuk harga diri berdasarkan konsentrasi adalah 6l,48. Ini menunjukkan bahwa nilai harga diri tertinggi adalah konsentrasi PAK, sedangkan terendah adalah PAR. 
2. Mean penerimaan sosial berdasarkan konsentrasi menunjukkan bahwa Teologi memiliki nilai 63,30; PAK adalah 65,92; Musik adalah 63,76; PAR adalah 67,33. Mean keseluruhan untuk penerimaan sosial berdasarkan konsentrasi adalah 64,63. Ini menunjukkan bahwa nilai penerimaan sosial tertinggi adalah konsentrasi PAR, sedangkan terendah adalah teologi.

3. Mean kepribadian yang sehat berdasarkan konsentrasi menunjukkan bahwa Teologi memiliki nilai 64,42; PAK adalah 66,81; Musik adalah 65,35; PAR adalah 67,66. Mean keseluruhan untuk harga diri berdasarkan konsentrasi adalah 65,71. Ini menunjukkan bahwa nilai harga diri tertinggi adalah konsentrasi PAR, sedangkan terendah adalah Teologi.

Uji Anova Satu Arah

1. Nilai F untuk harga diri berdasarkan konsentrasi adalah 0,292 sedangkan propabilitas signifikannya adalah 0,831 atau 83\% lebih besar dari alpha $5 \%$. Ini berarti bahwa tidak terdapat perbedaan yang siginifikan akan nilai harga diri di dalam maupun di antara konsentrasi Ilmu Teologi, PAK, Musik, dan PAR.

2. Nilai F untuk penerimaan sosial berdasarkan konsentrasi adalah 1,938 sedangkan propabilitas signifikannya adalah 0,129 atau 12,9\% lebih besar dari alpha 5\%. Ini berarti bahwa tidak terdapat perbedaan yang signifikan akan nilai penerimaan sosial di dalam maupun di antara konsentrasi Ilmu Teologi, PAK, Musik, dan PAR.

3. Nilai F untuk kepribadian yang sehat berdasarkan konsentrasi adalah 1,693 sedangkan propabilitas signifikansi adalah 0,174 atau 17,4\% lebih besar dari alpha $5 \%$. Ini berarti bahwa tidak terdapat perbedaan yang signifikan akan nilai kepribadian yang sehat di dalam maupun di antara konsentrasi Ilmu Teologi, PAK, Musik, dan PAR.

\section{Berdasarkan Indeks Prestasi}

Analisa Mean (skor rata-rata):

1. Mean harga diri berdasarkan indeks prestasi menunjukkan bahwa IP 3,50-4,00 memiliki nilai 60,7l; IP 3,00-3,49 adalah 62,53; IP 2,50-2,99 adalah 60,92; IP 1,00-1,99 adalah 64,50. Mean keseluruhan untuk harga diri berdasarkan indeks prestasi adalah 61,84. Ini menunjukkan bahwa nilai harga diri tertinggi adalah mereka yang memiliki IP 1,00-1,99, sedangkan terendah adalah IP 3,50-4,00.

2. Mean penerimaan sosial berdasarkan indeks prestasi menunjukkan bahwa IP 3,50-4,00 memiliki nilai 65,90; IP 3,00-3,49 adalah 64,32; IP 2,50-2,99 adalah 63,95; IP 1,00-1,99 adalah 77,50. Mean keseluruhan untuk harga diri berdasarkan indeks prestasi adalah 64,63. Ini menunjukkan bahwa nilai penerimaan sosial tertinggi adalah mereka yang memiliki IP 1,00-1,99, sedangkan terendah adalah IP 2,50-2,99.

3. Mean kepribadian yang sehat berdasarkan indeks prestasi menunjukkan bahwa IP 3,50-4,00 memiliki nilai 66,5l; IP 3,00-3,49 
adalah 66,16; IP 2,50-2,99 adalah 64,32; IP 1,00-1,99 adalah 76. Mean keseluruhan untuk harga diri berdasarkan indeks prestasi adalah 65,71. Ini menunjukkan bahwa nilai harga diri tertinggi adalah mereka yang memiliki IP 1,00-1,99, sedangkan terendah adalah 2,50-2,99.

Uji Anova Satu Arah

1. Nilai F untuk harga diri berdasarkan indeks pretasi adalah 0,773 sedangkan propabilitas signifikannya adalah 0,546 atau 54,6\% lebih besar dari alpha $5 \%$. Ini berarti bahwa tidak terdapat perbedaan yang signifikan akan nilai harga diri, baik di dalam maupun di antara kelompok yang memiliki indeks prestasi 1,00-1,99; 2,00-2,99; 3,00-3,50; 3,50-400.

2. Nilai $F$ untuk penerimaan sosial berdasarkan indeks prestasi adalah 4,009 sedangkan propabilitas signifikannya adalah 0,05 atau 5\% sama dengan alpha 5\%. Ini berarti bahwa terdapat perbedaan yang signifikan akan nilai penerimaan sosial, baik di dalam maupun di antara kelompok yang memiliki indeks prestasi 1,00-1,99; 2,00-2,99; 3,00-3,50; 3,50-400. Perbedaan yang menyolok muncul pada kelompok yang memiliki indeks prestasi 1,00-1,99.

3. Nilai F untuk kepribadian yang sehat berdasarkan indeks prestasi adalah 3,658 sedangkan propabilitas signifikansi adalah 0,008 atau 0,8\% lebih kecil dari alpha 5\%. Ini berarti bahwa terdapat perbedaan yang signifikan akan nilai kepribadian yang sehat, baik di dalam maupun di antara kelompok yang memiliki indeks prestasi 1,00-1,99; 2,00-2,99; 3,00-3,50; 3,50-400.

\section{Berdasarkan Status Pernikahan}

\section{Analisa Mean (skor rata-rata):}

1. Mean harga diri berdasarkan status pernikahan menunjukkan bahwa yang telah menikah memiliki nilai 65,00 dan yang belum menikah sebesar 61,66. Mean keseluruhan untuk harga diri berdasarkan status pernikahan adalah 61,84. Mereka yang telah menikah memiliki harga diri yang lebih baik dari pada mereka yang belum menikah.

2. Mean penerimaan sosial berdasarkan status pernikahan menunjukkan bahwa mereka yang telah menikah memiliki nilai 73,50 sedangkan yang belum menikah adalah 64,33. Mean keseluruhan untuk harga diri berdasarkan status pernikahan adalah 64,63.

3. Mean kepribadian yang sehat berdasarkan status pernikahan menunjukkan bahwa mereka yang telah menikah memiliki nilai sebesar 75,00 sedangkan yang belum menikah sebesar 65,44. Mean keseluruhan untuk kepribadian yang sehat berdasarkan status pernikahan adalah 65,71 .

\section{Uji Anova Satu Arah}

1. Nilai F untuk harga diri berdasarkan status pernihakan adalah 0,868 sedangkan propabilitas signifikannya adalah 0,423 atau 42,3\% lebih besar dari alpha $5 \%$. Ini berarti bahwa tidak terdapat perbedaan yang 
signifikan akan nilai harga diri, baik di antara dan di dalam kelompok yang sudah menikah atau belum menikah.

2. Nilai F untuk penerimaan sosial berdasarkan status pernikahan adalah 3,255 sedangkan propabilitas signifikannya adalah 0,043 atau 4,3\% lebih besar dari alpha 5\%. Ini berarti bahwa terdapat perbedaan yang signifikan akan nilai penerimaan sosial, baik di antara dan di dalam kelompok yang sudah menikah atau belum menikah.

3. Nilai F untuk kepribadian yang sehat berdasarkan status pernikahan adalah 4,163 sedangkan propabilitas signifikansi adalah 0,019 atau 1,9\% lebih kecil dari alpha 5\%. Ini berarti bahwa terdapat perbedaan yang signifikan akan kepribadian yang sehat, baik di antara dan di dalam kelompok yang sudah menikah atau belum menikah.

\section{Analisis Korelasi}

Analisis Korelasi adalah analisa yang dilaksanakan untuk melihat hubungan antara variabel-variabel dan menguji serta menjawab hipotesis berbentuk asosiatif. Analisis Korelasi digunakan untuk melihat kekuatan hubungan antara variabel bebas (independent) dan variabel terikat (dependent). Nilai korelasi ( $r$ ) mempunyai interval antara $+1,00$ dan 1,00. Semakin dekat nilai korelasi $\mathrm{r}$ dengan +1 atau -1 , semakin kuat hubungan antara kedua variabel. Nilai korelasi menunjukkan hubungan signifikan antara variabel bebas dan variabel terikat. Sedangkan jika nilai korelasi $\mathrm{r}=0$ menunjukkan tidak ada hubungan yang signifikan antara variabel bebas dan variabel terikat.

Hipotesis penelitian: terdapat korelasi signifikan antara harga diri dan penerimaan sosial terhadap kepribadian yang sehat. Hipotesis statistik: Ho : $r=0$ (tidak terdapat korelasi secara signifikan antara harga diri dan penerimaan sosial terhadap kepribadian yang sehat; $\mathrm{Hl}$ : $\mathrm{r}$ tidak sama dengan 0 (terdapat korelasi secara signifikan antara harga diri dan penerimaan sosial terhadap kepribadian yang sehat); dengan tingkat signifikansi dan daerah penerimaan/penolakan alfa 5\%.

Adapun pedoman interpretasi Nilai Korelasi Variabel Penelitian adalah:

\begin{tabular}{|l|l|}
\hline \multicolumn{1}{|c|}{ Korelasi } & \multicolumn{1}{c|}{ Tingkat Hubungan } \\
\hline $0,80-1.00$ atau $80-100 \%$ & Sangat Kuat \\
\hline $0,60-0,799$ atau $60-79 \%$ & Kuat \\
\hline $0,40-0,599$ atau $40-59 \%$ & Sedang \\
\hline $0,20-0,399$ atau $20-39 \%$ & Rendah \\
\hline $0,001-0,199$ atau $1-19 \%$ & Sangat Rendah \\
\hline 0,00 & Tidak ada Korelasi \\
\hline
\end{tabular}

\section{Korelasi Harga Diri terhadap Kepribadian yang Sehat}

Dari hasil output analisa nilai korelasi koefisien didapat besar $\mathrm{r}$ sebesar 0,309. Hal ini menunjukkan bahwa terdapat korelasi antara harga 
diri dan kepribadian yang sehat. Hasilnya adalah positif, berkorelasi rendah, dan searah.

Hasil signifikan (2tailed) diperoleh nilai sebesar 0,003 $<0,05$. Ini menunjukkan bahwa terdapat hubungan secara signifikan antara harga diri dan kepribadian yang sehat (HO ditolak dan $\mathrm{Hl}$ diterima).

\section{Korelasi Penerimaan Sosial terhadap Kepribadian yang Sehat}

Dari hasil output analisa nilai korelasi koefisien didapat besar $\mathrm{r}$ sebesar 0,330. Hal ini menunjukkan bahwa terdapat korelasi penerimaan sosial dan kepribadian yang sehat. Hasilnya adalah positif, berkorelasi rendah, dan searah.

Hasil signifikan (2tailed) diperoleh nilai sebesar 0,001<0,05. Ini menunjukkan bahwa terdapat hubungan secara signifikan antara penerimaan sosial dan kepribadian yang sehat ( $\mathrm{HO}$ ditolak dan $\mathrm{Hl}$ diterima).

\section{Analisis Regresi Berganda}

Analisis Regresi digunakan untuk memprediksikan pengaruh nilai variabel dependent (terikat) berdasarkan nilai variabel independent (bebas). Analisis Regresi dilakukan untuk mengetahui hubungan antara dua variabel atau lebih yang bersifat kasual (sebab akibat). Analisis Regresi digunakan juga untuk menjawab hipotesis Nol tentang pengaruh dua atau lebih variabel bebas terhadap variabel terikat.

Hipotesis penelitian: terdapat korelasi antara harga diri dan penerimaan sosial terhadap kepribadian yang sehat. Hipotesis statistik: H0: bl=b2=0 (tidak terdapat korelasi yang signifikan antara harga diri dan penerimaan sosial terhadap kepribadian yang sehat); Hl: bl tidak sama dengan b2 tidak sama dengan 0 (terdapat korelasi signifikan antara harga diri dan penerimaan sosial terhadap kepribadian yang sehat); dengan tingkat signifikansi dan daerah penerimaan/penolakan alpha 5\%. (bl dan b2 adalah koefisien regresi (nilai peningkatan dan penurunan).

Uji anova menunjukkan bahwa F hitung sebesar 14,092 < dari F 19,49, maka rata-rata variabel yang ada identik atau tidak terdapat perbedaan yang signifikan antara harga diri, penerimaan sosial, dan kepribadian yang sehat ( $\mathrm{HO}$ diterima dan $\mathrm{Hl}$ ditolak).

Terlihat F hitung sebesar 14,092 dengan propabilitas 0,000. Oleh karena propabilitas $0,000<0,05$, maka tidak terdapat perbedaan yang signifikan antara harga diri, penerimaan sosial, dan kepribadian yang sehat (HO diterima dan $\mathrm{Hl}$ ditolak).

Nilai Y= a adalah 28,609 ditambah nilai blXl sebesar 0,299 ditambah nilai b2X2 sebesar 0,288.

Koefisien regresi variabel harga diri sebesar 0,299, artinya jika penerimaan sosial memiliki nilai yang tetap, dan nilai harga diri ditingkatkan, maka kepribadian yang sehat meningkat pula. 
Koefisien regresi variabel penerimaan sosial sebesar 0,288, artinya jika harga diri memiliki nilai yang tetap, dan penerimaan sosial ditingkankan, maka kepribadian yang sehat akan meningkat pula.

Nilai $\mathrm{P}$ value $(\mathrm{Xl})$ sebesar $0,003<0,05$ berarti terdapat pengaruh yang siginifikan harga diri terhadap kepribadian yang sehat (H0 ditolak dan $\mathrm{Hl}$ diterima). Nilai $\mathrm{P}$ value (X2) sebesar $0,001<0,05$ berarti terdapat pengaruh signifikan penerimaan sosial terhadap kepribadian yang sehat (HO ditolak dan $\mathrm{Hl}$ diterima).

Berdasarkan data yang ada menunjukkan bahwa ketergantungan variabel Y (kepribadian yang sehat) pada variabel Xl (harga diri) dan X2 (penerimaan sosial) sebesar $r=49,3 \%$. Sedangkan nilai $r 2$ (square) sebesar 0,243 , menunjukkan bahwa 24,3\% dari perubahan kepribadian yang sehat (Y) disebabkan oleh kombinasi harga diri (X1) dan penerimaan sosial (X2), sedangkan $75,7 \%$ ditentukan oleh faktor-faktor lain.

\section{Pembahasan \\ Harga Diri}

Ditemukan bahwa nilai rata-rata harga diri mahasiswa STT Jaffray berdasarkan jenis kelamin 61,48 dan tidak ada perbedaan harga diri yang signifikan di antara pria $(61,47)$ dan wanita $(62,27)$ karena kedua-duanya memiliki nilai yang hampir sama, namun dari nilai yang ada menunjukkan bahwa harga diri mahasiswa puteri lebih baik dari mahasiswa putera.

Penilaian harga diri berdasarkan kelompok umur mahasiswa STT Jaffray ditemukan bahwa nilai rata-rata sebesar 61,84 dan tidak ada perbedaan yang signifikan di antara kelompok umur 17-20 (61,78), 21-24 $(62,26), 25-30$ (61,21), 31-35 (61), dan 35 ke atas (56), namun dari nilai yang ada menunjukkan bahwa nilai terendah adalah kelompok usia 35 tahun ke atas dan tertinggi adalah 21-24 tahun.

Nilai rata-rata harga diri mahasiswa STT Jaffray berdasarkan angkatan ditemukan sebesar 61,83 dan tidak ada perbedaan nilai yang signifikan di antara kelompok angkatan yang ada. Kelompok angkatan yang memiliki nilai terendah adalah 2007 (61.06) dan yang tertinggi adalah angkatan 2008 (62,29).

Nilai rata-rata harga diri mahasiswa STT Jaffray berdasarkan konsentrasi ditemukan sebesar 61,48 dan tidak ada perbedaan nilai yang signifikan di antara kelompok konsentrasi yang ada. Kelompok konsentrasi yang memiliki nilai terendah adalah PAR $(60,76)$ dan yang tertinggi adalah PAK $(62,36)$.

Nilai rata-rata harga diri mahasiswa STT Jaffray berdasarkan indeks prestasi ditemukan sebesar 61,84 dan tidak ada perbedaan nilai yang signifikan di antara kelompok indeks prestasi yang ada. Kelompok indeks prestasi yang memiliki nilai terendah adalah mereka yang memiliki IP 3,50$4,00(60,71)$ dan yang tertingi adalah mereka yang memiliki IP 1,00-1,99 $(64,50)$. 
Nilai rata-rata harga diri mahasiswa STT Jaffray berdasarkan status pernikahan ditemukan sebesar 61,84 dan tidak ada perbedaan nilai yang signifikan di antara kelompok status pernikahan yang ada. Kelompok status pernikahan yang memiliki nilai rendah adalah mereka yang belum menikah $(61,66)$ dan yang tertinggi adalah mereka yang sudah menikah (65).

Berdasarkan Analisa Korelasi Berganda, terdapat korelasi yang signifikan harga diri terhadap kepribadian yang sehat pada mahasiswa STT Jaffray, dengan nilai korelasi positif, rendah, dan searah.

Berdasarkan analisis Regresi Berganda, nilai koefieisen regresi mahasiswa STT Jaffray untuk harga diri sebesar 0,299. Ini berarti bahwa, walaupun penerimaan sosial nilainya tetap, tetapi jika diupayakan peningkatan harga diri mahasiswa STT Jaffray, maka kepribadian yang sehat mahasiswa akan meningkat pula.

\section{Penerimaan Sosial}

Ditemukan bahwa nilai rata-rata penerimaan sosial mahasiswa STT Jaffray berdasarkan jenis kelamin sebesar 64,63 dan tidak ada perbedaan yang signifikan di antara pria $(64,06)$ dan wanita $(65,29)$ karena keduaduanya memiliki nilai yang hampir sama, namun dari nilai yang ada menunjukkan bahwa penerimaan sosial mahasiswa puteri lebih baik dari mahasiswa putera.

Penilaian penerimaan sosial berdasarkan kelompok umur mahasiswa STT Jaffray ditemukan bahwa nilai rata-rata sebesar 64,63 dan tidak ada perbedaan nilai yang signifikan di antara kelompok umur. Kelompok umur yang nilainya tertinggi adalah 17-20 tahun $(65,54)$ dan terendah adalah 3135 tahun ke atas (57).

Nilai rata-rata penerimaan sosial mahasiswa STT Jaffray berdasarkan angkatan ditemukan sebesar 64,63 dan tidak ada perbedaan nilai yang signifikan di antara kelompok angkatan yang ada. Kelompok angkatan yang terendah adalah $2006(63,81)$ dan yang tertinggi adalah angkatan 2008 $(65,46)$.

Nilai rata-rata penerimaan sosial mahasiswa STT Jaffray berdasarkan konsentrasi ditemukan sebesar 64,63 dan tidak ada perbedaan nilai yang signifikan di antara kelompok konsentrasi yang ada. Kelompok konsentrasi yang memiliki nilai terendah adalah Ilmu Teologi $(63,30)$ dan yang tertinggi adalah PAR $(63,76)$.

Nilai rata-rata penerimaan sosial mahasiswa STT Jaffray berdasarkan indeks prestasi ditemukan sebesar 64,63. Dari nilai yang ada menunjukkan perbedaan nilai yang signifikan di antara kelompok indeks prestasi yang ada. Kelompok indeks prestasi yang memiliki nilai terendah adalah mereka yang memiliki IP 2,50-2,99 $(63,95)$ dan yang tertinggi adalah mereka yang memiliki IP 1,00-1,99 (77,50).

Nilai rata-rata penerimaan sosial mahasiswa STT Jaffray berdasarkan status pernikahan ditemukan sebesar 64,63 dan terdapat perbedaan nilai 
yang signifikan di antara kelompok status pernikahan yang ada. Kelompok status pernikahan yang memiliki nilai terendah adalah mereka yang belum menikah $(64,33)$ dan yang tertinggi adalah telah menikah $(73,50)$.

Berdasarkan Analisa Korelasi, terdapat korelasi yang signifikan penerimaan sosial terhadap kepribadian yang sehat pada mahasiswa STT Jaffray, yang mana penerimaan sosial memiliki pengaruh terhadap kepribadian dengan nilai signifikansi positif, berkorelasi rendah, dan searah.

Berdasarkan analisis Regresi Berganda, nilai koefiisen regresi mahasiswa STT Jaffray untuk penerimaan sosial sebesar 0,288. Ini berarti bahwa, walaupun nilai harga dirinya tetap, tetapi diupayakan peningkatan penerimaan sosial mahasiswa STT Jaffray, maka kepribadian yang sehat mahasiswa akan meningkat pula.

\section{Kepribadian yang Sehat}

Ditemukan bahwa nilai rata-rata kepribadian yang sehat dari mahasiswa STT Jaffray berdasarkan jenis kelamin sebesar 65,71 dan tidak ada perbedaan yang signifikan di antara pria $(65,31)$ dan wanita $(66,18)$ karena kedua-duanya memiliki nilai yang hampir sama, namun dari nilai yang ada menunjukkan bahwa kepribadian yang baik mahasiswa puteri lebih baik dari mahasiswa putera.

Penilaian kepribadian yang sehat dari mahasiswa STT Jaffray berdasarkan kelompok umur ditemukan bahwa nilai rata-rata sebesar 65,71 dan tidak ada perbedaan yang signifikan di antara kelompok umur. Kelompok umur yang nilainya tertinggi adalah usia 17-20 tahun $(66,85)$ dan terendah adalah usia 31-35 tahun dan 35 ke atas (63).

Nilai rata-rata kepribadian yang sehat mahasiswa STT Jaffray berdasarkan angkatan ditemukan sebesar 65,71 dan tidak ada perbedaan yang signifikan di antara kelompok angkatan yang ada. Kelompok angkatan yang terendak adalah $2007(66,39)$ dan yang tertinggi adalah angkatan $2008(65,17)$.

Nilai rata-rata kepribadian yang sehat mahasiswa STT Jaffray berdasarkan konsentrasi ditemukan sebesar 65,71 dan tidak ada perbedaan nilai yang signifikan di antara kelompok konsentrasi yang ada. Kelompok konsentrasi yang memiliki nilai terendah adalah Teologi $(64,42)$ dan yang tertinggi adalah PAR $(67,66)$.

Nilai rata-rata kepribadian yang sehat mahasiswa STT Jaffray berdasarkan indeks prestasi ditemukan sebesar 65,71. Data menunjukkan bahwa terdapat perbedaan nilai yang signifikan di antara kelompok indeks prestasi yang ada. Kelompok indeks prestasi yang memiliki nilai terendah mereka yang memiliki IP 2,50-2,99 $(65,32)$ dan yang tertinggi adalah mereka yang memiliki IP 1,00-1,99 (76).

Nilai rata-rata kepribadian yang sehat mahasiswa STT Jaffray berdasarkan status pernikahan ditemukan sebesar 65,71 dan terdapat perbedaan nilai yang signifikan di antara kelompok status pernikahan yang 
ada. Kelompok status pernikahan yang memiliki nilai rendah adalah yang belum menikah $(65,44)$ dan yang tinggi adalah yang telah menikah $(75)$.

Berdasarkan Analisa Korelasi, diketahui bahwa terdapat korelasi signifkan antara harga diri dan penerimaan sosial terhadap kepribadian yang sehat mahasiswa STT Jaffray, dengan nilai positif, rendah, dan searah.

Berdasarkan Analisa Regresi Koefisien, nilai harga diri mahasiswa STT Jaffray $(X 1=0,003)$ dan penerimaan sosial $(X 2=0,001)$ menunjukkan bahwa terdapat pengaruh yang signifikan antara harga diri dan penerimaan sosial terhadap kepribadian yang sehat pada mahasiswa STT Jaffray.

Berdasarkan data yang ada menunjukkan bahwa ketergantungan kepribadian yang sehat mahasiswa STT Jaffray pada harga diri dan penerimaan sosial sebesar r 0,439 atau 49,3\%. Sedangkan nilai r2 (square) sebesar 0,243, menunjukkan bahwa 24,3\% dari perubahan kepribadian yang sehat $(\mathrm{Y})$ disebabkan oleh kombinasi harga diri (Xl) dan penerimaan sosial (X2), sedangkan 75,7\% ditentukan oleh faktor-faktor lain.

\section{PENUTUP}

\section{Kesimpulan}

Hasil penelitian Korelasi antara Harga Diri dan Penerimaan Sosial terhadap Kepribadian Yang Sehat pada Mahasiswa STT Jaffray Makassar menunjukkan bahwa:

- Terdapat korelasi yang signifikan antara harga diri dan penerimaan sosial terhadap kepribadian yang sehat pada Mahasiswa STT Jaffray Makassar. Baik harga diri, penerimaan sosial, maupun kepribadian yang sehat memiliki keterkaitan dengan nilai positif, rendah, dan searah.

- Harga diri, penerimaan sosial, dan kepribadian yang sehat dari mahasiswa STT Jaffray tidak bergantung pada jenis kelamin, usia, angkatan, konsentrasi, dan indeks prestasi. Kategori-kategori yang ada tidak menjamin para mahasiswa STT Jaffray untuk memiliki kepribadian yang baik.

- Jika harga diri mahasiswa yang ada tetap nilainya, tetapi penerimaan sosialnya ditingkatkan maka akan berperanguh kepada pembentukan kepribadian yang sehat pada mahasiswa STT Jaffray Makassar. Atau jika penerimaan sosial yang ada tetap nilainya, tetapi harga dirinya ditingkatkan maka akan berpengaruh kepada pembentukan kepribadian yang sehat pada mahasiswa.

- Berdasarkan Analisa Korelasi, terdapat korelasi yang signifikan antara harga diri dan penerimaan sosial terhadap kepribadian yang sehat pada mahasiswa STT Jaffray, yang positif, berkorelasi rendah, dan searah. 
- Berdasarkan Analisa Regresi model Summary menunjukkan bahwa besar nilai (R) korelasi antara harga diri dan penerimaan sosial terhadap kepribadian yang sehat sebesar 0.493, berarti kombinasi harga diri dan penerimaan sosial yang dimiliki oleh mahasiswa STT Jaffray memberikan kontribusi terhadap kepribadian yang sehat sebesar 49,3\%, sedangkan 50,7\% adalah sumbangan faktor-faktor yang lain.

- Berdasarkan model Summary diketahui bahwa nilai R2 (square) sebesar 0,243, dengan maksud, 24,3\% dari perubahan yang terjadi pada kepribadian yang sehat dari mahasiswa STFT disebabkan oleh kombinasi harga diri dan penerimaan sosial, sedangkan $75,7 \%$ adalah kombinasi faktor-faktor yang lain.

\section{Saran}

- Diperlukan komunitas yang terbuka dan menerima mahasiswa apa adanya dengan, baik di kalangan mahasiswa dengan mahasiswa, maupun di kalangan mahasiswa dengan dosen dan karyawan.

- Diperlukan bimbingan konseling secara khusus kepada para mahasiswa yang tidak memiliki kepribadian yang baik yang disebabkan oleh kurangnya penghargaan diri dan penerimaan sosial serta menggali penyebab-penyebabnya dan memberikan bimbingan pemulihan kepada mereka. Atau melaksanakan kelompok bimbingan oleh dosen konseling atau mahasiswa program konseling pascasarjana, secara khusus bagi mereka yang bermasalah dengan harga diri dan penerimaan sosial. (Saran Ketua STT Jaffray).

- Diperlukan pembinaan soft skill dan pengajaran-pengajaran yang berkisar pada harga diri, penerimaan sosial, dan kepribadian yang baik dalam kegiatan-kegiatan gabungan pada acara-acara ibadah kapel atau kelompok doa dosen; atau dilaksanakan pengarahan-pengarahan berdasarkan kelompok umur, jenis kelamin, angkatan, konsentrasi, dan status perkawinan.

- Diperlukan Pelatihan Pengenalan Diri berdasarkan pemahaman terhadap Harga Diri dan Penerimaan Sosial pada Mahasiswa STT Jaffray Makassar dengan mengadakan tes sebelum dan sesudah pelatihan sebagai Penelitian Lanjutan.

- Perlu dilaksanakan penelitian lanjutan tentang Faktor-Faktor Penyebab Terbentuknya Harga Diri dan Penerimaan Sosial dan Akibatnya pada Mahasiswa STT Jaffray Makassar. 